\title{
Assessing the Impact of Government Initiatives on Reducing Poverty amongst Women at Professor Dora Akunyili Women Development Centre in Anambra State, Nigeria
}

\author{
${ }^{1}$ Onugu Charles U., ${ }^{2}$ Anumudu Oluchi O. \& ${ }^{3}$ Obianefo Chukwujekwu A. \\ ${ }^{1 \& 2}$ Department of Agricultural Economics and Extension, Nnamdi Azikiwe University, Awka \\ ${ }^{3}$ Anambra State IFAD assisted Value Chain Development Programme, Awka, Nigeria
}

\begin{abstract}
The study examined the impact of Government Initiatives of reducing poverty amongst women in Anambra state based on a case study of Professor Dora Akunyili Women Development centre. The paper focused on the activities of the centre in championing poverty reduction among women. A wellstructured questionnaire was used to elicit information from randomly selected 112 trainees for the study. Descriptive statistics such as frequency, percentage and mean were used. Percentage difference was equally used to ascertain the difference in poverty status of women before and after the training. The study showed that the trainees had mean income of \$50,405.56 and \$151,338.89 before and after the training; mean savings before and after the training was $\$ 35,741.11$ and \$48,150.00; mean expenditure on household food was $\$ 21,266.67$ and $\$ 38,111.11$ before and after the training; mean expenditure on household health before and after

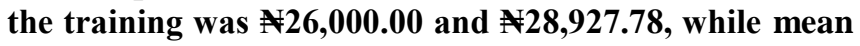
expenditure on household assets acquisition before and after the training was $\$ 27,811.11$ and $\$ 55,075$.00 respectively. The major challenges faced by the trainees were administrative bottlenecks and bureaucracy in the release of capital funds, late arrival of materials used for the training, among others.
\end{abstract}

Keyword:- Poverty, Savings, Asset Acquisition, Percentage Difference, Entrepreneurial Activities.

\section{INTRODUCTION}

Poverty can be said to be a universal occurrence which affects nations and people differently and which afflicts people in various depths and levels at different times and different phases of existence. The level of the problem in developing countries can be said to have reached alarming proportions. Nnamani (2010), defined Poverty as a state where an individual is not able to cater adequately for his or her basic needs of food, shelter and clothing, unable to meet social and economic obligations, lacks gainful employment, skills, assets and has limited access to social and economic infrastructure such as education, health, electricity, good road network, portable water and sanitation. Babatunde, Olorunsanya and Adejola (2008) in Omoniyi (2013), asserted that about 1.2 billion people globally are living in extreme poverty, that is less than one dollar per day, and, that reducing or combatting it has been a great concern to many countries especially Nigeria in the past few decades. Though, there have been a lot of improvements in the developed world but such cannot be said of developing countries especially in Sub-Sahara Africa.

Nigeria is a Federal Republic of 36 states and a Federal capital territory, with a population of above 190 million people as at 2017 (Worldometers, 2017). About 70\% of the Nigerian population reside in the rural areas and spend their livelihoods there. One common feature of Nigerian rural areas is poverty which is on the high side. The persistence and pervasiveness of poverty in the rural areas of Nigeria remains one of the most pressing problems confronting rural governance in Nigeria today. However, in a bid to reduce the increasing rate of poverty in the country, various governments have adopted different poverty alleviation programmes. Prominently among them are National Accelerated Food Production Programme (NAFPP) in 1973, Operation Feed the Nation (OFN) in 1976, The Green Revolution Programme (GRP) in 1979, National Directorate of Employment (NDE) in 1989, The Directorate for Food, Road and Rural Infrastructure (DFFRI) in 1986, Better Life for Rural Women (BLRW) in 1987, Poverty Alleviation Programme (PAP) in 1986, National Poverty Eradication Programme (NAPEP) in 2001, Women Development Programme (WDP) in 2000 among others. Between 2003 and 2007, the Nigerian Government implemented an economic reform programme called National Economic Empowerment Development Strategy (NEEDS) to raise the country's standard of living through a variety of reforms including the micro economic stability, deregulation, liberalization, privatization, transparency and accountability. The United Nations also sponsored National Millennium Goals between 2000 and 2015 aimed at poverty reduction, education, gender equality and health (Wikipedia, 2017). Despite the change in the names of various programmes aimed at alleviating rural poverty and the huge amount of money government has injected into the programme, poverty rate remains high and the standard of living continue to decline (Anyebe, 2014).

Over the last decade, several works have indeed been done by different scholars to determine how poverty alleviation programmes has reduced poverty rate and improve standard of living in Nigeria. Anyebe (2014), 
Obikezie et.al (2015), Omoniyi (2013), Onwe \& Nwakamma (2015) investigated the challenges of ending rural poverty using the National Poverty Eradication Programme (NAPEP) as a Government Development Programme to reduce poverty at the grassroots. Also, Maria (2015) and Ugbajah \& Ugumba (2013) carried out a study on cooperative organizations and micro credit as a means of poverty alleviation and rural community development in Nigeria. They discovered that the Government Development Programmes are merged in mixed bag of limited success and continuing challenges. Presently, Professor Dora Akunyili Women Development Centre in Anambra state, Nigeria is a new development programme for reducing poverty amongst women. The centre was created in Anambra state in 1996 under the Ministry of women affairs and social welfare. It was later renamed to Professor Dora Akunyili Women Development centre by the state Governor, Willie Obiano in year 2015 in honour of Professor Dora Akunyili, an illustrious indigene of Anambra state who died of cancer in 2014. The aim of the programme is to reduce poverty drastically amongst women and children through life improvement activities and income generation by acquisition of skills. Having been in existence for over two decades, the researchers felt the need to explore its developmental impact on women. Hence, the quest to investigate the difference in the income, savings, and household's expenditure on food, health and asset acquisitions before and after the trainings of women at the centre cannot be overemphasized.

\section{Objectives of the study}

The main objective of the study is to assess the impact of government initiatives of reducing poverty amongst women (trainees) at the Professor Dora Akunyili Women Development centre in Anambra state, Nigeria. Specifically, the study is designed to:

i. investigate the activities carried out at the centre on women poverty reduction,

ii. determine the extent to which the activities carried out at the centre aided the reduction of poverty amongst the women, and

iii. assess the challenges faced by the women (trainees) at the centre and proffer remedies.

\section{RESEARCH METHODOLOGY}

\section{$>$ The Study Area}

The study was carried out at Prof. Dora Akunyili women development center, Awka, Anambra State. The State comprises of 21 (Aguata, Awka North, Awka South, Anambra East, Anambra West, Anaocha, Ayamelum, Dunukofia, Ekwusigo, Idemili North, Idemili South, Ihiala, Njikoka, Nnewi North, Nnewi South, Ogbaru, Onitsha North, Onitsha South, Orumba North, Orumba South and Oyi) local government area from where all the trainees at the center cut across. The center is located in Awka South (the administrative headquarter of Anambra State) sitting on latitude; $6.2116^{\circ} \mathrm{N}$ and longitude; $7.0714^{\circ} \mathrm{E}$.
Sampling Procedure and Method of Data Collection

For in-depth observation of the study representative, a case study research was adopted. The center principal provided the list (sample frame) of graduates from inception (2001) till date (2019) according to their local government participation. For convenience and timeliness, the study collected data from two (2) local government areas (Awka North and South) due to also being the Local government with the highest number of participants. $70 \%$ of the 160 trainees from the two (2) local government areas were randomly sampled to give a sample size of 112 respondents for the study.

\section{METHOD OF DATA ANALYSIS}

A descriptive statistics was used to operationalize all the construct of the study, while percentage difference was used to ascertain the significant difference in their income, savings and household expenditures on food, health and asset acquisitions. Thus, the model is explicitly stated as follows;

\section{A. descriptive statistics model for the objectives:}

$\overline{\mathrm{X}}=\sum \frac{\mathrm{FX}}{\mathrm{n}} * \frac{100}{1} \ldots . . . E q n .1$

Where:

$\overline{\mathrm{X}}=$ Mean, $\mathrm{F}=$ Frequency, $\mathrm{X}=$ Variables, $\mathrm{n}=$ Sample size.

B. percentage difference

$\mathrm{PD}=\frac{\mathrm{Y}_{2}-\mathrm{Y}_{1}}{\overline{\mathrm{X}}} * 100 \ldots . . . E q n .2$

$\overline{\mathrm{X}}=\frac{\mathrm{Y}_{2}+\mathrm{Y}_{1}}{2} \ldots . . . E q n .3$

Where:

$\mathrm{PD}=$ percentage difference, $\mathrm{Y}_{2}=$ mean income, savings, expenditure after the training at the center, $\mathrm{Y}_{1}=$ mean income, savings, expenditure before the training at the center, $\overline{\mathrm{X}}=$ as earlier defined

\section{RESULTS AND DISCUSSION}

\section{Entrepreneurial Activities Executed at Professor Dora} Akunyili Women Development Centre, Awka

The entrepreneurial activities executed at Prof. Dora Akunyili Women Development Centre, Awka is presented in Table 1. Respondents were allowed multiple response to the questions asked. The Table shows that the majority $(80.0 \%)$ of the trainees acquired skills on fashion designing, while $72.2 \%, 53.3 \%, 52.2 \%$ and $30.0 \%$ acquired entrepreneurial skills on catering, cosmetology, art \& craft and computer skills. None of the trainees had training on stage decoration, event management, furniture making, metal work, auto mechanics, crop farming, livestock farming, fishery \& aquiculture, poultry and food processing. 
This implies that most of the women prefer softer skills moreso as they are urban and semi-urban dwellers. This is in agreement with Yahaya and Luka (2012) who suggested that the trainees have been trained adequately in various skills that will eventually enable them do well in their own environment and private businesses.

\begin{tabular}{|c|c|c|c|}
\hline S/N & Vocational activities & Frequency (n= 112) & Percentage (\%) \\
\hline i. & Clothe making/ fashion designing & 72 & 80.00 \\
\hline ii. & Catering services/Food makers (ice cream, cakes) & 65 & 72.22 \\
\hline iii. & Information Technology/Computer Skills & 27 & 30.00 \\
\hline iv. & Arts and Crafts (Beads making, pots, among others) & 47 & 52.22 \\
\hline v. & Cosmetology (Hair making, pedicure, among others) & 48 & 0.33 \\
\hline vi. & Stage decoration & 0 & 0.00 \\
\hline vii. & Event Management (party, wedding, among others) & 0 & 0.00 \\
\hline viii. & Wood Works/Furniture making & 0 & 0.00 \\
\hline ix. & Metal works & 0 & 0.00 \\
\hline x. & Auto-Mechanics & 0 & 0.00 \\
\hline xi. & Crop Farming & 0 & 0.00 \\
\hline xii. & Fishery and Aquaculture & 0 & 0.00 \\
\hline xiii. & Poultry & 0 & 0.00 \\
\hline xiv. & Food processing (soya bean, among others) & 0.00 \\
\hline xv. & Table & 0 & \\
\hline
\end{tabular}

Table 1:- Distribution of trainees according to entrepreneurial skills acquired.

Source: Field Survey Data, 2019. *Multiple response.

\section{> Impact of Professor Dora Akunyili Women Development Centre on Income status of the Trainees before and after the training}

The impact of Professor Dora Akunyili Women Development Centre on income status of the Trainees before and after the training is presented in Table 2. The information gotten from the field work was analyzed as presented in the Table 2. Income is the value of money that an individual or business receives in exchange for providing a good or service or through investment (Okechukwu, 2015). The table shows that the majority (63.3\% and $43.3 \%)$ of the trainee's income before and after the training ranges from $\$ 20,000-\$ 50,000$ and $\$ 101,000-\$ 200,000$ respectively. The mean average monthly income before and after the training was $\$ 50,405.56$ and $\$ 151,338.89$ respectively. The percentage difference in income status before and after the training was $100.1 \%$. Thus, the training received had above $100 \%$ improvement in the income status of the trainees. This supports the work of Chukwu (2011) who assert that improved income has positive effect in reducing poverty status in the rural areas.

\begin{tabular}{|c|c|c|c|c|}
\hline Sn. & Estimate of Income & Frequency $(n=112)$ & Percentage (\%) & Mean (N) \\
\hline $\begin{array}{l}1 . \\
2\end{array}$ & $\begin{array}{c}\text { Before: } \\
\$ 20,000-\$ 50,000 \\
\$ 51,000-\$ 100,000 \\
\$ 101,000-\$ 150,000 \\
\$ 151,000-\$ 200,000 \\
\text { After: } \\
\$ 20,000-\$ 100,000 \\
\$ 101,000-\$ 200,000 \\
\$ 201,000-\$ 300,000 \\
\$ 301,000 \text { and above }\end{array}$ & $\begin{array}{c}57 \\
32 \\
1 \\
0 \\
\\
29 \\
39 \\
17 \\
5\end{array}$ & $\begin{array}{c}63.33 \\
35.56 \\
1.11 \\
0.00 \\
\\
32.22 \\
43.33 \\
18.89 \\
5.56 \\
\end{array}$ & $\begin{array}{r}50405.56 \\
151338.89 \\
\end{array}$ \\
\hline & percentage difference & & 100.1 & \\
\hline
\end{tabular}

Table 2:- Distribution of Trainees According to Income before and after the training.

Source: Field Survey Data, 2019.

Also, two sample z-test was used to ascertain the influence of the training at the center on the income of the women. Finding shows that the mean income of $\$ 50,405.56$ before the training and $\$ 151,338.89$ after the training had a standard deviation of $21,018.57$ and $82,615.52$ respectively. The $\mathrm{z}$-value of 11.23 significant at $1 \%$ level of probability was greater than the table value of 1.96 at $5 \%$ level of probability, thus the null hypothesis was rejected and conclude that there was an improvement in their income. By implication, their participation enhanced their income which is an indices of poverty reduction. The result is in agreement with the work of Chukwu (2011) on poverty alleviation programme that the higher the income, the better their standard of living.

The significant difference in the income of the trainee's before and after the training is presented in table 3 . 
ISSN No:-2456-2165

\begin{tabular}{|c|c|c|c|c|c|c|}
\hline Variable & Mean & Std. dev. & DF & Z-cal. & Z- tab. & Decision \\
\hline Initial income & $\mathbf{N 5 0 4 0 5 . 5 6}$ & 21018.57 & 178 & -11.23 & 1.96 & Reject the null hypothesis \\
\hline Income after training & $\$ 151338.89$ & 82615.52 & & & & \\
\hline
\end{tabular}

Table 3: Summary of Statistical difference in income of Women before and after the training $(n=90)$.

Source: Field Data, 2019. (*) Significant at 5\% level of probability.

Impact of Professor Dora Akunyili Women Development Centre on Savings status of the Trainees before and after the training

The impact of Professor Dora Akunyili Women Development Centre on savings status of the Trainees before and after the training is presented in Table 4. The Table shows that the majority $(76.7 \%$ and $56.7 \%)$ of the trainees had saving between $\$ 5,100$ - $\$ 10,000$ and $\$ 21,000$ - $\$ 50,000$ before and after the training respectively.
The mean monthly savings before the training was N35741.11 and N48150.00 after the training. Thus, the trainee's savings status improved by $29.6 \%$. The trainee's savings culture is still very low and was not in line with Chukwu (2011) in which savings leads to improved income and at the same time reduces poverty in the lives of the participants in Suleja Local Government Area of Niger State, Nigeria.

\begin{tabular}{|c|c|c|c|c|}
\hline Sn. & Estimate of savings & Frequency $(n=112)$ & Percentage (\%) & Mean (N) \\
\hline \multirow[t]{5}{*}{1} & Before & & & \\
\hline & $\$ 2,000-\$ 5,000$ & 0 & 0.00 & \\
\hline & $\$ 5,100-\mathbf{N 1 0 , 0 0 0}$ & 69 & 76.67 & 35741.11 \\
\hline & 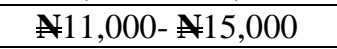 & 15 & 16.67 & \\
\hline & $\$ 15,100$ - above & 6 & 6.67 & \\
\hline \multirow[t]{6}{*}{2} & After & & & \\
\hline & $\mathbf{N} 4,000-\mathbf{N} 20,000$ & 9 & 10.00 & \\
\hline &  & 51 & 56.67 & 48150.00 \\
\hline & 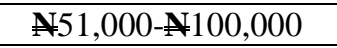 & 27 & 30.00 & \\
\hline & $\mathbf{N 1 0 1 , 0 0 0 - \text { above }}$ & 3 & 3.33 & \\
\hline & Percentage difference & & 29.6 & \\
\hline
\end{tabular}

Table 4:- Distribution of Trainees According to savings before and after the training. Source: Field Survey Data, 2019.

The significant difference in the savings of trainees before and after the training was equally analyzed from the information generated though the questionnaire using the $\mathrm{z}$ test statistics at $5 \%$ level of probability. The results gotten from the analysis shows that the mean savings before the training was $\$ 35,741.11 \mathrm{~K}$ and after the training was $\$ 48,150.00 \mathrm{~K}$ respectively. Since the $\mathrm{Z}$ - calculated (1.82) is less than $\mathrm{Z}$ - tabulated (1.96), the implication is that we accept the null hypothesis $2\left(\mathrm{HO}_{2}\right)$ that says there is no significant difference between the savings of women before and after their training at Prof. Dora Akunyili Women Development Centre. The trainees need to be educated on the importance of saving some portions of their income.

The significant difference in the savings of the trainee's before and after the training is presented in table 5 .

\begin{tabular}{|c|c|c|c|c|c|c|}
\hline Variable & Mean & Std. dev. & DF & Z-cal. & Z- tab. & Decision \\
\hline Initial savings & $\$ 35741.11$ & 59549.69 & 178 & -1.82 & 1.96 & Accept the null hypothesis \\
\hline Savings after training & $\$ 48150.00$ & 25543.14 & & & & \\
\hline
\end{tabular}

Table 5:- Summary of Statistical difference in the savings of women before and after the training (n=90). Source: Field Data, 2019. (*) Significant at $5 \%$ level of probability.

Impact of Professor Dora Akunyili Women Development Centre on household food expenditure status of the Trainees before and after the training

The impact of Professor Dora Akunyili Women Development Centre on household food expenditure status of the Trainees before and after the training is presented in Table 6. The Table shows that the majority $(40.0 \%$ and $38.9 \%$ ) of the trainees spend between $\$ 11,000-\$ 20,000$ and $\$ 5,000$ - $\$ 30,000$ before and after the training respectively. The mean expenditure on household food before and after the training was \$21,266.67 and
N38,111.11 respectively and the percentage difference in food expenditure status was $56.7 \%$. It is an indication that there was an increase in their expenditure on household food as a result of the skills they received from the center. According to Nugawela (2012), expenditure on food simply means the amount of money that is spent on food consumption, Payment of cash or cash-equivalent for foods, or a charge against available funds in settlement of an obligation. Therefore, entrepreneurial training increased the food expenditure status of the trainees. 
ISSN No:-2456-2165

\begin{tabular}{|c|c|c|c|c|}
\hline Sn. & Expenditure on food & Frequency (n=112) & Percentage (\%) & Mean (N) \\
\hline $\mathbf{1}$ & Before & & & \\
\hline & N5,000 - N10,000 & 19 & 21.11 & $\mathbf{2 1 2 6 6 . 6 7}$ \\
\hline & N11,000 - N20,000 & 36 & 40.00 & \\
\hline & N21,000 - N30,000 & 14 & 20.00 & \\
\hline & N40,000 - above & 18 & & \\
\hline 2 & After & 35 & 38.89 & \\
\hline & N5,000 - N30,000 & 28 & 31.11 & \\
\hline & N31,000 - N50,000 & 25 & 27.78 & $\mathbf{3 8 1 1 1 . 1 1}$ \\
\hline & N51,000 - N70,000 & 2 & $\mathbf{5 6 . 7}$ & \\
\hline & N71,000 - above & & 22 & \\
\hline
\end{tabular}

Table 6:- Distribution of Trainees according to the Expenditure on household food before and after the training.

Source: Field Survey Data, 2019.

The significant difference in the expenditure on household food before and after the training was analyzed using the z-test statistics at 5\% level of probability. The table shows that the mean amount spent on household food before the training was $1266.67 \mathrm{~K}$ and after the training was $\$ 38,111.11 \mathrm{~K}$. Since the Z-calculated (6.93) is greater than Z-tabulated (1.96), we reject the null hypothesis. The implication of this is that significant difference exist between the expenditure on household food of the trainees before and after the training; we therefore reject the null hypothesis $3\left(\mathrm{HO}_{3}\right)$ that says there is no significant difference between the expenditure on food of women before and after their training at Prof. Dora Akunyili Women Development Centre and accept the alternate hypothesis. This therefore shows that the food needs of the women and their households improved after their training at the center.

The significant difference in the expenditure on food of the women before and after the training is presented in table 7 .

\begin{tabular}{|c|c|c|c|c|c|c|}
\hline Variable & Mean & Std. dev. & DF & $\mathbf{Z}$ - cal. & $\mathbf{Z}$ - tab. & Decision \\
\hline Initial spending on food & $\$ 21266.67$ & 13106.14 & 178 & -6.93 & 1.96 & Reject the null hypothesis \\
\hline Expenditure on food after training & $\mathbf{N} 38111.11$ & 18977.04 & & & & \\
\hline
\end{tabular}

Table 7:- Summary of Statistical difference on food expenditure of the women before and after the training $(n=90)$. Source: Field Data, 2019. (*) Significant at $5 \%$ level of probability.

Impact of Professor Dora Akunyili Women Development Centre on household health expenditure status of the Trainees before and after the training

The impact of Professor Dora Akunyili Women Development Centre on household food expenditure status of the Trainees before and after the training is presented in Table 8 . The Table shows that the majority $(41.1 \%$ and
43.3\%) spends N20,000- N30,000 and N31,000- N50,000 before and after the training respectively. The mean monthly expenditure on health before and after the training was $\$ 26,000.00$ and $\$ 28,927.78$ respectively and the percentage difference was $10.7 \%$. There was a slight difference in expenditure on household health as a result of the entrepreneurial training received.

\begin{tabular}{|c|c|c|c|c|}
\hline Sn. & Expenditure on health & Frequency $(n=112)$ & Percentage $(\%)$ & $\operatorname{Mean}(\mathbf{N})$ \\
\hline \multirow[t]{5}{*}{1} & Before & & & \\
\hline & $<\mathrm{N} 20,000$ & 34 & 37.78 & \\
\hline & $\mathrm{N} 20,000-\mathrm{N} 30,000$ & 37 & 41.11 & 26000.00 \\
\hline & $\mathrm{N} 31,000-\mathrm{N} 45,000$ & 15 & 16.67 & \\
\hline & N50,000 - above & 4 & 4.44 & \\
\hline \multirow[t]{6}{*}{2} & After & & & \\
\hline & $\mathrm{N} 5,000-\mathrm{N} 30,000$ & 9 & 10.00 & \\
\hline & N31,000- N50,000 & 39 & 43.33 & \\
\hline & N51,000- N75,000 & 18 & 20.00 & 28927.78 \\
\hline & N75, 100 - above & 24 & 26.67 & \\
\hline & Percentage Difference & & 10.7 & \\
\hline
\end{tabular}

Table 8:- Distribution of Trainees According to Expenditure on household health before and after the training.

Source: Field Survey Data, 2019. 
The significant difference in expenditure on health before and after the training was analyzed using the z-test statistics at $5 \%$ level of probability. The table shows that the mean amount spent on family health before the training was $\$ 26,000.00$ and after the training was $\$ 28,927.78$. Since the Z-calculated (1.43) is less than Z-tabulated (1.96), we accept the null hypothesis and reject alternate hypothesis. The implication of this is that significant difference does not exist between the expenditure on health of the trainees and their households before and after the training. We therefore accept hypothesis 4 that says there is no significant difference between the expenditure on health of women before and after their training at Prof. Dora Akunyili Women Development Centre.

The significant difference on household health expenditure of the trainees before and after the training is presented in table 9.

\begin{tabular}{|c|c|c|c|c|c|c|}
\hline Variable & Mean & Std. dev. & DF & Z-cal. & Z- tab. & Decision \\
\hline Initial spending on health & $\$ 26000.00$ & 6936.71 & 178 & -1.43 & 1.96 & $\begin{array}{l}\text { Accept the null } \\
\text { hypothesis }\end{array}$ \\
\hline Spending on health after training & $\mathbf{N} 28927.78$ & 18213.86 & & & & \\
\hline
\end{tabular}

Table 9:- Summary of Statistical Difference on health expenditure of women before and after the training $(n=90)$. Source: Field Data, 2019. (*) Significant at $5 \%$ level of probability.

Impact of Professor Dora Akunyili Women Development Centre on household health expenditure status of the Trainees before and after the training

The impact of Professor Dora Akunyili Women Development Centre on household asset acquisition status of the Trainees before and after the training is presented in Table 10 .

The Table shows that the majority ( $41.1 \%$ and $43.3 \%)$ of the trainees asset acquisition before and after the training ranges from N20,000 - N39,000 and N31,000 - N50,000 respectively. The mean household assets acquisition by the women before and after the training was $\$ 27,811.11$ and \$55,075.00 respectively and the percentage difference was 98.0\%. By implications, the trainee's participation in the center enhanced their acquisition of household assets. This is in line with Ntalwila, Mrisha, Mwakatobe and Kohi (2017) who assert that the trainings received has contributed significantly in household assets acquisition of the participants.

\begin{tabular}{|c|c|c|c|c|}
\hline Sn. & Expenditure on asset & Frequency $(n=112)$ & Percentage $(\%)$ & Mean (N) \\
\hline \multirow[t]{5}{*}{1} & Before & & & \\
\hline & $<\mathrm{N} 20,000$ & 34 & 37.78 & \\
\hline & $\mathrm{N} 20,000-\mathrm{N} 39,000$ & 37 & 41.11 & 27811.11 \\
\hline & $\mathrm{N} 40,000$ - N59,000 & 15 & 16.67 & \\
\hline & N60,000 - above & 4 & 4.44 & \\
\hline \multirow[t]{6}{*}{2} & After & & & \\
\hline & 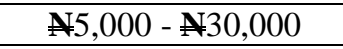 & 9 & 10.00 & \\
\hline & $\$ 31,000-\mathbf{N 5 0 , 0 0 0}$ & 39 & 43.33 & \\
\hline & 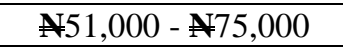 & 18 & 20.00 & 55075.00 \\
\hline & $\mathbf{N 5 , 1 0 0 - \text { above }}$ & 24 & 26.67 & \\
\hline & Percentage Difference & & 98.0 & \\
\hline
\end{tabular}

Table 10: Distribution of Trainees According to Household Assets before and after the Training.

Source: Field Survey Data, 2019.

The significant difference on expenditure of household assets before and after the training was analyzed using the $\mathrm{z}-$ test statistics at $5 \%$ level of probability. The table shows that the mean amount spent on household assets before the training was $\$ 27,811.11$ and after the training was \$55,075.00. Since the Z-calculated (9.39) is greater than Ztabulated (1.96), we therefore reject the null hypothesis that says there is no significant difference between the expenditure on household assets of women before and after their training at Prof. Dora Akunyili Women Development Centre, and accept the alternate hypothesis. We conclude that there was an improvement in their household assets. By implications, their participation in the centre enhanced their acquisition of household assets. This is in line with Ntalwila, Mrisha, Mwakatobe and Kohi (2017) that the trainings received has contributed significantly in household assets acquisition of the participants.

The significant difference in expenditure on household assets of the trainees before and after the training is presented in table 11 .

\begin{tabular}{|c|c|c|c|c|c|c|}
\hline Variable & Mean & Std. dev. & DF & $\mathbf{Z}$ - cal. & Z- tab. & Decision \\
\hline Initial spending on household assets & $\mathbf{N} 27811.11$ & 16131.23 & 178 & -9.39 & 1.96 & Reject the null hypothesis \\
\hline Spending on household assets after training & $\mathbf{N} 55075.00$ & 22328.57 & & & & \\
\hline
\end{tabular}

Table 11: Summary of Statistical difference on expenditure of household assets of women before and after the training ( $\mathrm{n}=90)$.

Source: Field Data, 2019. (*) Significant at 5\% level of probability. 
Challenges Faced by the Trainees of Professor Dora Akunyili Women Development Centre

The setback faced by the trainees of the centre is presented in table 12. The Table shows that the majority $(88.9 \%)$ of them are faced with Non-availability of state of art skill acquisition equipment $(88.89 \%)$, late arrival of materials used for the training (85.56\%), administrative bottlenecks and bureaucracy in the release of capital funds
$(81.11 \%)$, poor provision of information to the trainees $(73.33 \%)$, poor funding of the programme $(72.22 \%)$, inadequate training and retraining of participants $(65.56 \%)$ and poor programme coordination $(65.56 \%)$. According to Anyebe (2014), inadequate funding, administrative bottlenecks, poor provision of information among others are the major challenges faced by government development programme when eliminating poverty.

\begin{tabular}{|c|c|c|c|}
\hline Sn. & Challenges & Frequency $(n=112)$ & Percentage $(\%)$ \\
\hline i. & Lack of awareness of the programme & 45 & 50.00 \\
\hline ii. & $\begin{array}{l}\text { Administrative bottlenecks and bureaucracy in release of capital } \\
\text { funds }\end{array}$ & 73 & 81.11 \\
\hline iii. & Late arrival of materials used for the training & 77 & 85.56 \\
\hline iv. & Inadequate training and retraining of participants & 59 & 65.56 \\
\hline $\mathrm{v}$. & Poor Programme Coordination & 59 & 65.56 \\
\hline vi. & Non availability of state of art skill acquisition equipment & 80 & 88.89 \\
\hline vii. & Poor funding of the programme & 65 & 72.22 \\
\hline viii. & Weak post monitoring of settled participants & 37 & 41.11 \\
\hline ix. & $\begin{array}{c}\text { Poor knowledge/skill of the Prof. Dora Akunyili women development } \\
\text { centre officials }\end{array}$ & 10 & 11.11 \\
\hline $\mathrm{x}$. & Poor commitment on the programme by the officials & 5 & 5.56 \\
\hline xi. & Poor provision of information to the trainees & 66 & 73.33 \\
\hline
\end{tabular}

Table 12: Distribution of Trainees According to Challenges Existing.

Source: Field Survey Data, 2019. *Multiple Response was recorded.

\section{CONCLUSION}

Poverty is a critical issue in developing countries which Nigeria belongs to. The vulnerability of rural poor household is more on female headed households, therefore necessitating the need to intensify efforts to building the capacity of women in order to build their economic capacity aimed at alleviating poverty from amongst them (women) especially in the rural areas. Therefore, the study on assessing the government initiatives of reducing poverty amongst women in Anambra state, Nigeria through Professor Dora Akunyili Women Development Centre, Awka cannot be overemphasized. Ideally, equipping the women with entrepreneurial skills such as clothe making/ fashion designing, catering services/Food makers (Ice cream, cakes) and information technology/computer skills among others have shown to have significantly improve the women's income, savings, expenditure on; household food, health and asset acquisition by $100.1 \%, 29.7 \%, 56.7 \%$, $10.7 \%$ and $98.0 \%$ respectively. Thus, the choice of the study was properly thought off. Though, policy makers need to carefully look into the following grey areas identified in the study (non-availability of state of art skill acquisition equipment, late arrival of materials used for the training, administrative bottlenecks and bureaucracy in release of capital funds, poor provision of information to the trainees and poor funding of the programme).

\section{REFERENCES}

[1]. Akinmulewo, B.O. (2016). Assessment of the Profitability of Improved Agriculture and its relationship to poverty status in Abuja, Nigeria. An unpublished Msc thesis in Agricultural Economics and Rural Sociology, Ahmadu Bello University, Zaria, Kaduna state.

[2]. Anyebe, A.A. (2014). Poverty reduction in Nigeria via National Poverty Eradication Programme (NAPEP): Two decades of policy failure? Journal of social science for policy implications. June 2014, vol. 2, No. 2, pp. 19-35. ISSN: 2334-2900 (Print), 2334-2919 (Online). Published by American Research Institute for Policy Development.

[3]. Babatunde, R.A., E.O. Olorunsanya and Adejola (2008). Assessment of rural household poverty: Evidence from south-western Nigeria. AmericanEurasian J, Agriculture and Environmental. Science. 3 (6): 900-905.

[4]. Caswell, M.K., C. Fuglie, S. Ingram, C. Jans, and Kascak. (2001). Adoption of Agricultural production practices: Lessons learned from the US. Department of Agriculture area studies project. Washington DC. US Department of Agriculture. Resource Economics Division, Economic Research service, Agriculture Economic Report No. 792.

[5]. Chukwu, B. I. (2011). The Impact of Government's Poverty Reduction Programmes in Niger State: A Case Study of Suleja Local Government Area, from 2006 
TO 2008. An unpublished thesis - Department of political science, university of Nsukka.

[6]. Maria, C. U (2015). Co-operative Organizations as a Means of Poverty Alleviation and Rural Community Development in Nigeria. International Journal of Economics, Commerce and Management United Kingdom. Vol. III, Issue 9, September 2015. Licensed under Creative Common Page 482. ISSN 23480386.

[7]. Emodi, A.I. (2009). Analysis of rice innovation system in Southeast Nigeria. $\mathrm{PhD}$ thesis, Department of Agricultural Extension, University of Nigeria, Nsukka, p. 51 .

[8]. Nnamani, T.J. (2010). An assessment of poverty reduction programme in Enugu state (204-2009). An unpublished thesis.

[9]. Ntalwila, J., C. Mrisha, A. Mwakatobe and E.M. Kohi (2017). Contribution of bee-keeping to Livelihood and biodiversity conservation in Inyonga Division (Mlele District) Western Tanzania. International Journal of Entomology Research. ISSN: 2455-4758. Vol. 2; Issue 6; November 2017; page no. 33-38.

[10]. Nugawela P. (2001) Committee of donor Agencies for Small Enterprise Development. Secretariat; SME Department, MSN F2K-207. World Bank Group 1818 H Street NW. Washington, DC 20043 USA: Fax: (202) 522-3742

[11]. Obikezie, O.S., M.O. Ananti and R.U. Onyekwelu (2015). The challenges of ending rural poverty. An appraisal of National Poverty Eradication Programme (NAPEP). Journal of policy and development studies. Vol. 9, No. 3,

[12]. Okechukwu, O.E. (2015). Government Spending on Poverty Alleviation through Cooperatives: A case study of Fadama III Project Crop Farmers' Cooperative Societies in Imo State (Nigeria). International Journal of Academic Research in Business and Social Sciences. Vol. 5, No. 3.

[13]. Oluwatusin, F.M. (2008). Cost and returns in modern beekeeping for honey production in Nigeria. Pakistan Journal of Social Sciences. 5: 310-315.

[14]. Omoniyi, V.A. (2013). Policy implementation and rural poverty reduction in Nigeria: An analysis of the National Poverty Eradication Programme (NAPEP) in Ado-Odo Ota local government area, Ogun state. Ist Annual International Interdisciplinary Conference, AIIC 2013, 24-26.

[15]. Onwe, S.O. and M.C. Nwakamma (2015). Assessment of National Poverty Reduction Programme in Nigeria: A study of National Eradication Programme (NAPEP), Ebonyi state. International Journal of Humanities and Social Science Vol. 5, No. 2; February 2015. 227

[16]. Ranjan, S. (2006). Occupational diversification and access to rural employment: Revisiting the non-farm employment debate Munich Personal Repec Archive (MPRA) paper Number 7870, 4-8.

[17]. Ugbajah, M.J and C. Ugwumba (2013). Analysis of Micro Credit as a Veritable Tool for Poverty Reduction among Rural Farmers in Anambra State, Nigeria. Discourse Journal of Agriculture and Food Sciences. ISSN: 2346-7002. October 2013. Vol. 1(10): 152-159.
[18]. Wikipedia (2017). Rate of unemployment in Nigeria from 2007 to 2016.

[19]. Worldometers (2017). www.worldometers.info.

[20]. Yahaya, H. and E.G. Luka (2012). The role of private Extension Agencies in Agricultural Development of Kaduna state, Nigeria: A case study of Leventis Foundation Agricultural Training School. Journal of Biology, Agriculture and Healthcare. Vol 2, No. 10, 2012. 